\title{
THE LOSS OF MERCURY FROM STORED SEA- WATER SOLUTIONS OF MERCURIC CHLORIDE
}

\author{
By E. D. S. CORNER \\ International Paints Research Fellow, The Laboratory, Plymouth \\ and F. H. RigLER \\ Zoology Dept., University of Toronto
}

(Text-figs. I and 2)

To assess the efficiency of an anti-fouling composition it is necessary to determine the rate at which the poison leaches from the paint film into the surrounding sea water. With a paint containing mercury this estimation is difficult because sea-water solutions of mercuric chloride are unstable. Thus, when examined by the chloroform-dithizone procedure (Harris, 1946) these solutions have been found to lose as much as $80 \%$ of their mercury content in the course of a week (Robinson, private communication).

In the present work, ${ }^{203} \mathrm{Hg}$-labelled mercuric chloride has been used for a quantitative and qualitative study of the loss of mercury from sea water, and the results of this investigation have demonstrated the considerable importance of bacteria as a factor in this process.

One of us (F. H. R.) is indebted to the National Research Council of Canada for a Research Fellowship to work at Plymouth, and the other wishes to acknowledge a Research Fellowship from International Paints Ltd. Both of us wish to express our thanks to Mr O. D. Hunt, Mr T. W. Robinson and Mr R. Robinson for their keen interest in this work, and to Dr H. W. Harvey, F.R.S., for his many helpful suggestions. We should also like to thank Dr B. C. Abbott for his advice on the use of radioactive materials, and Mr L. Hummerstone for the maintenance of the counting equipment.

\section{PRELIMINARY EXPERIMENTS}

\section{Chloroform-dithizone titrations}

Mercuric chloride was added to filtered Plymouth sea water to give a concentration of $0.1 \mathrm{mg} \mathrm{Hg} / 1$. $\left(0.5 \times 10^{-6} \mathrm{M}\right)$, and estimations were made daily by means of the chloroform-dithizone procedure to determine the quantity of mercury present in the solution. The results of experiments with plain sea water, and with sea water to which $40 \%$ formaldehyde had been added 
( $5 \mathrm{ml} . / 1$.$) , are shown in Table I. For the purposes of tracer isotope studies it$ was thought necessary to use a higher concentration of mercuric chloride, and further estimations were therefore carried out using a sea-water solution of this compound containing I mg $\mathrm{Hg} / \mathrm{l}$. The results of this experiment are also included in Table $\mathrm{I}$. In these experiments, which were carried out at I6-I $8^{\circ} \mathrm{C}$, it was found that after one week only a very small proportion of the mercury originally added to untreated sea water could be detected, but that $80 \%$ of the mercury could still be found in sea-water solutions containing formaldehyde.

TABLE 1. RATES OF LOSS OF MERCURY FROM SOLUTIONS OF MERCURIC CHLORIDE IN PLAIN SEA WATER AND IN SEA WATER CONTAINING FORMALDEHYDE

(Concentration of $40 \% \mathrm{HCHO}=5 \mathrm{ml} . / 1$. of sea water. Experiment carried out at $16^{\circ} \mathrm{C}$ )

\begin{tabular}{|c|c|c|c|}
\hline \multirow[b]{3}{*}{ Day } & \multicolumn{3}{|c|}{$\begin{array}{l}\text { Chloroform-dithizone } \\
\text { titres (ml.) }\end{array}$} \\
\hline & \multicolumn{2}{|c|}{ Plain sea water } & \multirow{2}{*}{$\begin{array}{l}\text { Formaldehyde- } \\
\text { treated sea water } \\
(0.1 \mathrm{mg} \mathrm{Hg} / \mathrm{l})\end{array}$} \\
\hline & (0.1 $\mathrm{mg} \mathrm{Hg} / \mathrm{l}$ ) & $(\mathrm{r} \circ \mathrm{mg} \mathrm{Hg} / \mathrm{l})$. & \\
\hline o & 26 & 240 & 25 \\
\hline I & 24 & 230 & \\
\hline 2 & 20 & 210 & 24 \\
\hline 3 & II & 120 & 24 \\
\hline & - & 50 & \\
\hline & - & 12 & - \\
\hline & - & 9 & - \\
\hline 7 & 5 & - & 20 \\
\hline
\end{tabular}

Prevention of mercury loss by various bactericides

It seemed possible that the role of formaldehyde in preventing mercury loss might be chemical rather than bactericidal. Accordingly, estimations were made of the loss of mercury from solutions of mercuric chloride ( $\mathrm{I} \mathrm{mg} \mathrm{Hg} / \mathrm{l}$ ) in sea water in which bacterial growth was prevented by several different methods. The results of this experiment are given in Table 2, which shows that, in addition to formalin, other treatments which would destroy bacteria or inhibit their growth, also prevented the loss of mercury from the sea water.

TABLE 2. LOSS OF MERCURY FROM SOLUTIONS OF MERCURIC CHLORIDE IN SEA WATER TREATED TO PREVENT BACTERIAL GROWTH

(Sea water saturated with chloroform and phenol; $40 \%$ formaldehyde used at a concentration of $5 \mathrm{ml}$./1.; penicillin and streptomycin each used at a concentration of $50 \mathrm{mg} / \mathrm{l}$.)

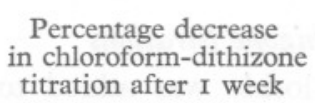
titration after I week

None

Treatment

Chloroform

74

Formaldehyde

Phenol

Penicillin and streptomycin

Autoclaving

○

0

4

9 


\section{QUANTITATIVE STUDIES USING TRACER ISOTOPES}

To examine whether or not the decrease in the chloroform-dithizone titre represented an actual loss of mercury from the sea water, experiments were carried out with radioactive mercuric chloride.

\section{MATERIALS AND METHODS}

Radioactive mercury $\left({ }^{203} \mathrm{Hg}\right)$ was obtained from Harwell as mercuric oxide and converted into the chloride by treatment with $50 \% \mathrm{HCl}$. Certain technical difficulties encountered in the estimation of radioactive mercury have been described by Kelly, Thorpe, Threefoot \& Burch (1950). In the present work it was found that the volatilization of mercury during the drying of radioactive samples was prevented if sodium sulphide was added to the solution before it was warmed to dryness on the planchette. Estimations of radioactivity were usually made with $0 . \mathrm{I} \mathrm{ml}$. samples of the sea-water solution which, when dried, were found to contain about $3 \mathrm{mg}$ solids $/ \mathrm{cm}^{2}$. The correction necessary for self-absorption in these samples was determined by comparing the number of counts/min. shown by samples prepared in sea water and in distilled water. This correction (2\%) was then applied in all subsequent estimations of radioactivity in sea-water samples. As a precaution, the decay curve of the radioactive material was plotted from measurements of radioactivity made at suitable intervals and was found to be similar to that shown by ${ }^{203} \mathrm{Hg}$ (half-life $=47 \cdot 9$ days).

\section{ESTIMATION OF MERCURY LOSS}

Sufficient radioactive mercuric chloride was added to sea water containing glucose and ferric ammonium citrate (to promote the growth of bacteria) to give a concentration of $\mathrm{I} \mathrm{mg} \mathrm{Hg} / \mathrm{l}$. Simultaneous estimations of the mercury present in the sea water by titration with chloroform-dithizone and by measurement of the amount of radioactivity in samples (0.1 ml.) of the sea water were then made immediately after the mercuric chloride was added to the sea water and at suitable intervals during the subsequent week. In addition, simultaneous determinations were made of the quantity of mercury present on bacteria in the solution by passing a sample (Io $\mathrm{ml}$.) through a millipore filter which was then examined for radioactivity.

The results of this experiment (see Fig. I) showed that during the first 2 days the loss of mercury as determined by chloroform-dithizone titration was approximately the same as that estimated from measurements of radioactivity in the sea water. This correlation disappeared, however, once a significant amount of mercury had been taken up by the bacteria, and as this quantity neared and passed its maximum value the chloroform-dithizone procedure detected much less mercury than was found to be present in the sea water by estimations of radioactivity. It is interesting to note that in this 
region of the curve the total amount of mercury present in the sea water was roughly the sum of the quantity taken up by bacteria and that detected by the chloroform-dithizone titrations, a finding which implied that the mercury held by the bacteria was not extracted by chloroform-dithizone. Of further interest was the finding that, during the latter part of the experiment, the quantity of mercury held by bacteria in suspension gradually diminished until, after 6 days, it had practically disappeared.

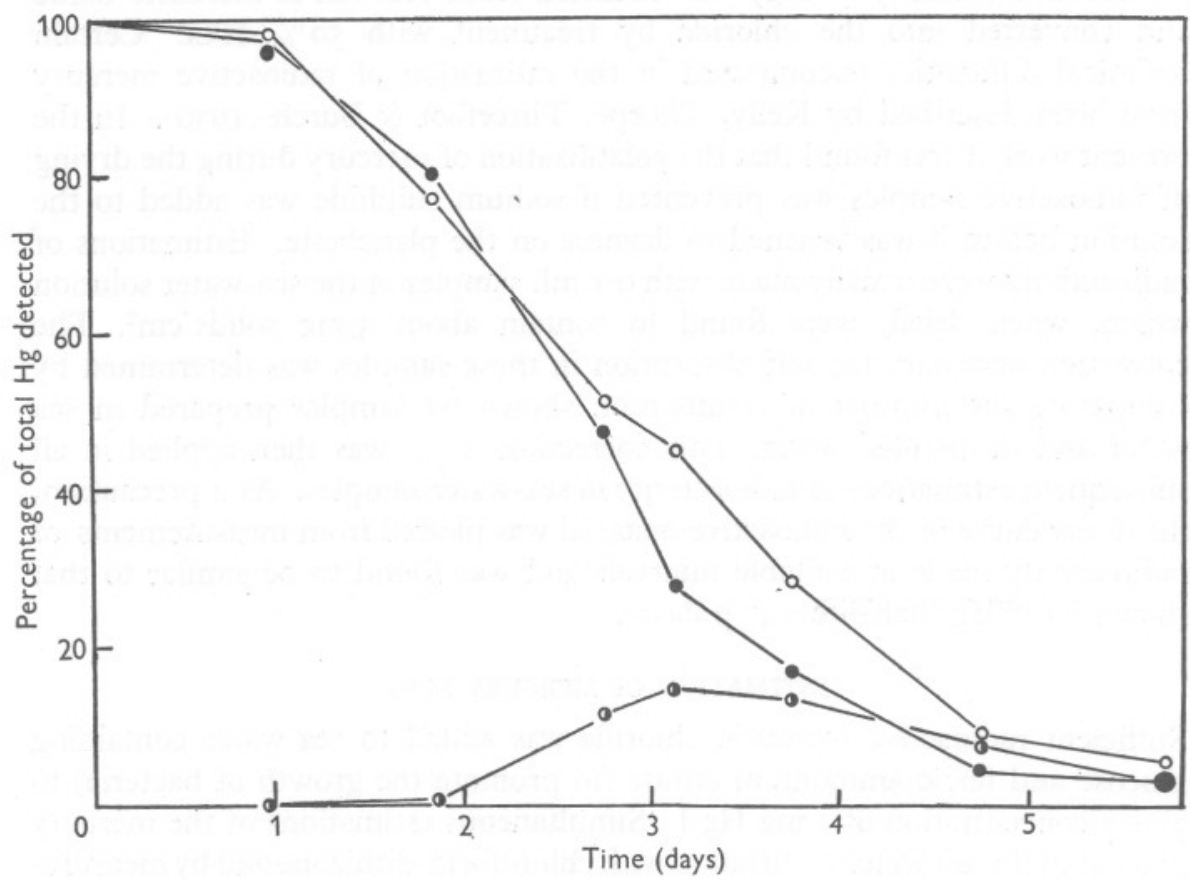

Fig. I. The loss of mercury as mercuric chloride ( $\mathrm{I} \mathrm{mg} \mathrm{Hg} / \mathrm{l}$.) from sea water as estimated by chloroform-dithizone titrations (-), and measurements of radioactivity in solution $(\mathrm{O}-\mathrm{O})$. The amounts of mercury present on suspended bacteria are also shown ( $-\mathrm{C})$.

\section{LOCATION OF THE LOST MERCURY}

Previous experiments had shown that the loss of mercury from stored sea-water solutions of mercuric chloride was genuine, and not simply the results of inadequacies in the chloroform-dithizone procedure. Further experiments were therefore made to locate the mercury which had been lost from solution.

Attachment to walls of storage vessel. In preliminary studies, flasks in which sea-water solutions of mercury had been stored were emptied and fumed out with conc. $\mathrm{HNO}_{3}$. The acid extract and the cleaned glass were then examined for radioactivity. On no occasion did the mercury so detected account for 
more than $\mathrm{I} \%$ of that lost. In later experiments, no preliminary treatment with acid was carried out: the flasks were emptied, drained, dried and smashed, and fragments of suitable size were immediately examined for radioactivity. When this procedure was used a much larger amount of mercury was detected, but this was still not enough to account for the total quantity lost. Because of this unexpected finding it became necessary to examine the possibility that some of the mercury had volatilized from solution.

Volatilization from solution. In these experiments a slow stream of air was passed over the sea-water solution and led out to the atmosphere through a series of traps containing various reagents. In the course of these studies the reagents used were ethanol, $o$-cyclohexanone, distilled-water solutions of cysteine and sodium sulphide, ethyl ether, activated animal charcoal, alumina, powdered silver, acidified permanganate, potassium iodide and sodium hypobromite. However, only charcoal was effective in trapping a significant amount of volatile radioactive compound(s). When the decay curve of this radioactive material trapped on the charcoal was plotted it was found to correspond to that for ${ }^{203} \mathrm{Hg}$. In different experiments the amounts of mercury detected on the charcoal varied from 5 to $25 \%$ of the quantity lost, the minimum value being obtained in an experiment with sea water containing nutrients, and the maximum with untreated sea water.

These preliminary studies led to three conclusions. The first was that some of the lost mercury had volatilized from solution and some had become attached to the walls of the glass vessel. The second was that the attached mercury could itself be converted into a volatile compound by treatment with conc. $\mathrm{HNO}_{3}$. Thirdly, it appeared that the distribution of the lost mercury between glass and vapour largely depended upon the conditions under which bacteria developed in the solution. In order to examine these possibilities further, the following experiments were carried out.

\section{INFLUENCE OF NUTRIENTS ON THE PATTERN OF MERCURY LOSS}

A sample $\left(200 \mathrm{ml}\right.$.) of sea water containing I $\mathrm{mg} \mathrm{Hg} / \mathrm{l}$. as ${ }^{203} \mathrm{Hg}$-labelled mercuric chloride was added to each of two flasks. One of the samples was enriched with glucose $(0.5 \mathrm{~g} / 1$.) and ferric ammonium citrate ( $\mathrm{I} \mathrm{mg/1}$.) to promote the growth of bacteria. No additions were made to the other sample. Each solution was examined daily for distribution of radioactivity between the solution, the suspended bacteria, and the walls of the vessel, the latter quantity being determined by estimating the radioactivity on a glass slide suspended vertically in the liquid.

The results of this experiment (Fig. 2) clearly show the influence of bacteria on mercury loss. Thus, compared with untreated sea water, the enriched sample lost mercury at a faster rate, the bacteria in it took up twice as much mercury as did those in the untreated sample, and about twice the quantity of mercury was lost to a glass slide suspended in the solution. There were, 
however, certain similarities between the two samples. Thus the amount of mercury removed by suspended bacteria passed through a maximum value at a time when approximately $50 \%$ of the mercury had been lost from solution, and the quantity detected on the glass slide rose to a peak one day later. It seemed surprising that the amount of mercury taken up by the glass slide did not continue to increase throughout the whole experiment, and to check this observation, at the end of the experiment the flasks containing the untreated and the enriched samples were emptied, dried, and smashed, and fragments were examined for mercury in the usual way. When this was done $18 \%$ of the lost

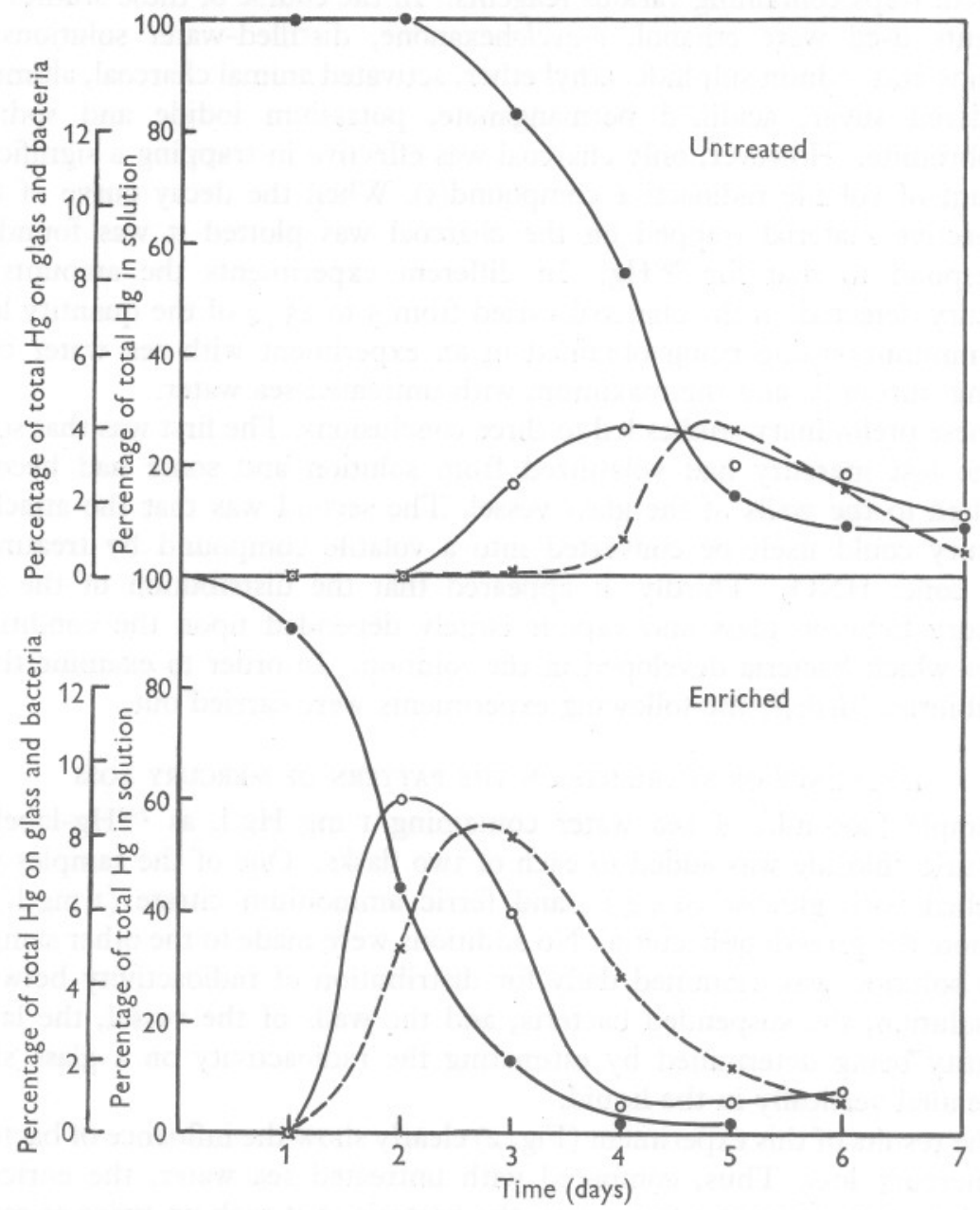

Fig. 2. Distributions of mercury between solution (-), suspended bacteria ( $\bigcirc-\bigcirc)$ and walls of the vessel $(x---x)$ after mercuric chloride ( $\mathrm{mg} \mathrm{Hg} / \mathrm{l}$.) had been added to enriched $(0.5 \mathrm{~g}$ glucose and $\mathrm{I} \mathrm{mg}$ ferric ammonium citrate/1.) and untreated sea water. 
mercury was detected on the flask which had contained the enriched sample and $9 \%$ on the flask which had held the untreated sample. As the values calculated from the radioactivity of the glass slides accounted for less than I \% of the mercury lost from each sample, it was obvious that during the latter half of the experiment, at least, measurement of the amount of mercury on a suspended glass slide was inadequate as an indication of the quantity adsorbed on the walls of the vessel. The reason for this discrepancy became clear when the distribution of mercury over the flask was examined at the end of the experiment, for whereas very little mercury could be detected on the sides, a large amount was found on the bottom of the vessel. It seemed, therefore, that most of the mercury which was lost from solution to the glass of the storage vessel was not fixed by sessile bacteria but sedimented either attached to bacteria themselves or as some insoluble derivative which they formed. Moreover, this sedimented mercury was very difficult to remove and was probably firmly attached to the bottom of the flask by the slimy bacterial film already present.

Next, an attempt was made to examine the possibility that mercury in a volatile form might be released by lysing the bacteria attached to the walls of the glass vessel. To do this, a sample of enriched sea water containing I $\mathrm{mg} \mathrm{Hg} / 1$. was allowed to stand at room temperature for 6 days, after which the solution was removed from the flask and replaced by acetone. The flask was then sealed, a column of activated animal charcoal was inserted between the acetone and the atmosphere, and a current of air was passed through the system for a further 6 days. The charcoal was then extruded from the column, thoroughly mixed and samples $(2-4 \mathrm{mg}$ ) then worked into a paste with absolute ethanol on planchettes. The samples were then slowly dried and examined for radioactivity. It was found in this experiment that the quantity of radioactivity on the charcoal column corresponded to $5 \%$ of the total amount of mercury originally added to the sea-water sample, and approximately one-third of the mercury attached to the glass of the vessel. An attempt to detect further quantities of volatile mercury by reassembling the apparatus with a column of fresh charcoal and continuing the experiment for a further 4 days was unsuccessful, for no additional quantity of volatile mercury was detected.

Further experiments were carried out in order to examine the influence of nutrients on the distribution of the lost mercury between the atmosphere and the surface of the glass vessel. In these experiments one enriched and one plain sea-water sample containing I mg Hg/l. (as ${ }^{203} \mathrm{Hg}$-labelled mercuric chloride) were placed in each of two flasks. The flasks were then sealed and a current of air was passed over the surface of each solution and out to the atmosphere through a column of activated animal charcoal. In order to avoid dismantling the assemblies, daily estimations of mercury loss from the two solutions were obtained from measurements of the radioactivity in identical 
samples prepared at the same time but left open to the atmosphere. When these estimations indicated that more than $80 \%$ of the mercury originally added to the solutions had been lost, the flasks equipped with charcoal columns were opened and each assembly was examined as follows. The sea water was removed from each flask which was then drained, dried and smashed, and fragments from the sides and bottom of the flask were then examined for radioactivity. Next, the charcoal was extruded from the column and examined for radioactivity. The results of these experiments are shown in Table 3, from which it is clearly seen that whereas a large proportion of the mercury lost from the plain sea-water sample was trapped on the

\begin{tabular}{|c|c|c|}
\hline \multicolumn{3}{|c|}{$\begin{array}{l}\text { THE PATTERN OF MERCURY LOSS } \\
\text { (Experiment carried out for } 6 \text { days at room temperature) }\end{array}$} \\
\hline & $\begin{array}{c}\text { Enriched } \\
\text { sea water } \\
(\%)\end{array}$ & $\begin{array}{c}\text { Untreated } \\
\text { sea water } \\
(\%)\end{array}$ \\
\hline Total amount of mercury lost & 86 & 55 \\
\hline Quantity adsorbed on charcoal & I5 & 34 \\
\hline Quantity attached to glass & 50 & I \\
\hline Percentage of lost mercury accounted for & 76 & 64 \\
\hline
\end{tabular}

charcoal column, only a small quantity was found on the glass. By contrast, however, in the case of the enriched sample, whereas a large amount of the lost mercury was detected on the glass, a considerably smaller fraction was found on the charcoal. In addition, it was found that the rate of loss of mercury from the plain sea-water solution contained in the flask equipped with a charcoal column was much slower than that from the solution which was exposed to the atmosphere. Thus, although measurements of the radioactivity present in this latter sample indicated that more than $80 \%$ of the mercury had gone from the solution in 6 days, similar determinations carried out on the other solution showed that, after 6 days, only $55 \%$ of the mercury originally added had been lost.

The experiments just described demonstrated that bacteria influence the loss of mercury from sea-water solutions both quantitatively and qualitatively. Thus, sea water enriched with nutrients loses mercury much faster than untreated sea water, and the distribution of the mercury between volatile compounds and the glass surface of the vessel is markedly different in the two cases, for whereas nutrients favour attachment to the glass, absence of nutrients favours volatilization. In conclusion, it should be stated that in none of these experiments has all the lost mercury been detected. However, it has been shown that part of the mercury on bacteria attached to the glass can be released as a volatile compound when these bacteria are lysed, and this finding draws attention to the possibility that some of the mercury may be volatilized from the flasks when these are dried prior to examination for radioactivity. 


\section{DISCUSSION}

The results of the present study have emphasized the importance of bacteria as a factor determining the loss of mercury from stored sea-water solutions of mercuric chloride. Consequently, when leaching rates of mercury from antifouling compositions are measured, care should be taken to prevent the growth of bacteria in the sea water in contact with the paint film. For not only do bacteria reduce the chloroform-dithizone titres by removing mercury from solution as a volatile compound (or compounds), they also cause a large quantity of the mercury to concentrate at the surface of the glass vessel, in which form it is no longer extracted into chloroform-dithizone.

At present it is not clear why part of the mercury is volatilized from the solution, and part is attached to the walls of the vessel; and, further, why the relative amounts of these fractions are changed by the presence of nutrients in the sea water. However, an observation by Ruska (1947) that certain bacteria can convert mercuric chloride into at least two products may provide a possible answer. For if the bacteria which arise in stored sea water convert the mercury into more than one compound then it is possible that the relative amounts of the compounds produced might depend on the conditions under which the bacteria develop. However, further speculation along these lines is not likely to be profitable until the identities of these compounds have been determined.

\section{SUMMARY}

The disappearance of mercury from stored sea-water solutions of mercuric chloride has been studied by means of the chloroform-dithizone procedure and by the use of radioactive mercury $\left({ }^{203} \mathrm{Hg}\right)$.

When sea water is enriched with nutrients facilitating the growth of bacteria, the rate at which mercury is lost from the solution is markedly increased. On the other hand, when the sea water is treated in various ways which prevent the development of bacteria, the loss of mercury from solution is considerably reduced.

Rates of loss of mercury measured by the chloroform-dithizone procedure and by the use of tracer isotopes are in good agreement only in the early stages of the experiments. Thus, at a time when approximately half the mercury has been lost, titrations with chloroform-dithizone only account for about $50 \%$ of the mercury determined by measurements of radioactivity. Further findings have suggested that this discrepancy arises from the fact that a considerable amount of the mercury is taken up by bacteria and converted into a form which is not detectable with chloroform-dithizone.

A comparison has been made of the patterns of mercury loss from plain sea water and from sea water containing nutrients promoting the growth of bacteria. The mercury lost from the former medium is produced mainly as a volatile compound, only a very small fraction being attached to the glass 
surface of the containing vessel. By contrast, a large amount of the mercury lost from the latter medium is attached to the glass and a significantly smaller fraction is volatilized. Some of the mercury attached to bacteria on the walls of the containing vessel can be released in the form of a volatile compound when the bacteria are lysed.

\section{REFERENCES}

HARRIS, J. E., 1946. Report on anti-fouling research. F. Iron St. Inst., Vol. 2, pp. $297-333$.

Kelly, F. J., Thorpe, C. R., Threefoot, S. H. \& Burch, G. E., I950. Influence of self-absorption, volatilization and deliquescence in counting of radioelements. f. Lab. clin. Med., Vol. 35, pp. 606-21.

Ruska, H., 1947. Fixation of mercuric chloride on bacteria and virus. Arch. exp. Path. Pharmak., Bd. 204, pp. 576-85. 